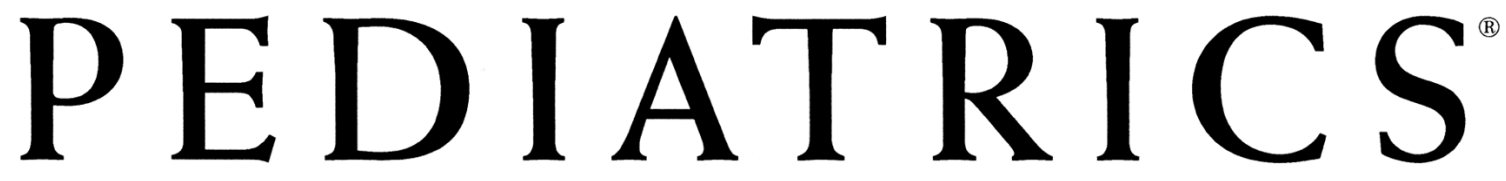

OFFICIAL JOURNAL OF THE AMERICAN ACADEMY OF PEDIATRICS

\title{
Consensus Statement on the Use of Gonadotropin-Releasing Hormone Analogs in Children
}

Jean-Claude Carel, Erica A. Eugster, Alan Rogol, Lucia Ghizzoni and Mark R. Palmert

Pediatrics 2009;123;e752; originally published online March 30, 2009;

DOI: $10.1542 /$ peds.2008-1783

The online version of this article, along with updated information and services, is located on the World Wide Web at: http://pediatrics.aappublications.org/content/123/4/e752.full.html

PEDIATRICS is the official journal of the American Academy of Pediatrics. A monthly publication, it has been published continuously since 1948. PEDIATRICS is owned, published, and trademarked by the American Academy of Pediatrics, 141 Northwest Point Boulevard, Elk Grove Village, Illinois, 60007. Copyright (๐ 2009 by the American Academy of Pediatrics. All rights reserved. Print ISSN: 0031-4005. Online ISSN: 1098-4275.

\section{American Academy of Pediatrics}




\title{
Consensus Statement on the Use of Gonadotropin-Releasing Hormone Analogs in Children
}

\author{
Jean-Claude Carel, MD, PhDa, Erica A. Eugster, MDb, Alan Rogol, MD, PhD ${ }^{\mathrm{b}, c}$, Lucia Ghizzoni, MDd, Mark R. Palmert, MD, PhD ${ }^{e, f}$, , on behalf of the \\ members of the ESPE-LWPES GnRH Analogs Consensus Conference Group
}

aDepartment of Pediatric Endocrinology and Diabetes, INSERM U690, and Centre de Référence des Maladies Endocriniennes de la Croissance, Robert Debré Hospital and University Paris 7 Denis Diderot, Paris, France; bSection of Pediatric Endocrinology, Department of Pediatrics, Riley Hospital for Children, Indiana University, Indianapolis,

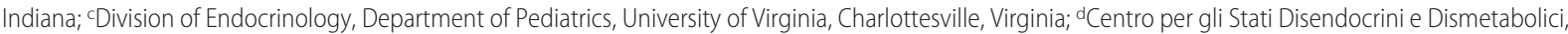
Dipartimento dell'Età Evolutiva, Università Degli Studi di Parma, Parma, Italy; eDivision of Endocrinology, Hospital for Sick Children, Toronto, Ontario, Canada; fDepartment of Pediatrics, University of Toronto, Toronto, Ontario, Canada

Financial Disclosure: Dr Carel has received grant funding from Ipsen and Takeda and received lecture fees from Ferring; Dr Eugster participates in clinical trials sponsored by Indevus and is a member of an advisory board for Indevus; Dr Rogol has been a consultant to Solvay, Teva, Tercica, Insmed, and Genentech and has equity in Insmed; and Dr Ghizzoni has received lecture fees from Ferring. Dr Palmert has indicated he has no financial relationships relevant to this article to disclose.

\section{ABSTRACT}

OBJECTIVE. Gonadotropin-releasing hormone analogs revolutionized the treatment of central precocious puberty. However, questions remain regarding their optimal use in central precocious puberty and other conditions. The Lawson Wilkins Pediatric Endocrine Society and the European Society for Pediatric Endocrinology convened a consensus conference to review the clinical use of gonadotropin-releasing hormone analogs in children and adolescents.

PARTICIPANTS. When selecting the 30 participants, consideration was given to equal representation from North America (United States and Canada) and Europe, an equal male/female ratio, and a balanced spectrum of professional seniority and expertise.

EVIDENCE. Preference was given to articles written in English with long-term outcome data. The US Public Health grading system was used to grade evidence and rate the strength of conclusions. When evidence was insufficient, conclusions were based on expert opinion.

CONSENSUS PROCESS. Participants were put into working groups with assigned topics and specific questions. Written materials were prepared and distributed before the conference, revised on the basis of input during the meeting, and presented to the full assembly for final review. If consensus could not be reached, conclusions were based on majority vote. All participants approved the final statement.

CONCLUSIONS. The efficacy of gonadotropin-releasing hormone analogs in increasing adult height is undisputed only in early-onset (girls $<6$ years old) central precocious puberty. Other key areas, such as the psychosocial effects of central precocious puberty and their alteration by gonadotropin-releasing hormone analogs, need additional study. Few controlled prospective studies have been performed with gonadotropin-releasing hormone analogs in children, and many conclusions rely in part on collective expert opinion. The conference did not endorse commonly voiced concerns regarding the use of gonadotropin-releasing hormone analogs, such as promotion of weight gain or long-term diminution of bone mineral density. Use of gonadotropin-releasing hormone analogs for conditions other than central precocious puberty requires additional investigation and cannot be suggested routinely. Pediatrics 2009;123:e752-e762 www.pediatrics.org/cgi/doi/10.1542/ peds.2008-1783

doi:10.1542/peds.2008-1783

Key Words precocious puberty, GnRH analogs, development

Abbreviations

GnRHa - gonadotropin-releasing hormone analog

CPP - central precocious puberty ESPE-European Society for Pediatric Endocrinology

LWPES—Lawson Wilkins Pediatric

Endocrine Society

$\mathrm{AH}$-adult height

$\mathrm{BA}$ - bone age

CA-chronological age

$\mathrm{LH}$-luteinizing hormone

FSH-follicle-stimulating hormone

SDS-SD score

GH_-growth hormone

BMD - bone mineral density

PCOS - polycystic ovarian syndrome

ISS-idiopathic short stature

SGA — small for gestational age

$\mathrm{CAH}$ - congenital adrenal hyperplasia

Accepted for publication Dec 2, 2008

Address correspondence to Jean-Claude Carel,

MD, PhD, Hôpital Robert Debré, Pediatric Endocrinology and Diabetes and INSERM U690, 48 Boulevard Sérurier, 75935 Paris, Cedex 19, France. E-mail: jean-claude.carel@ inserm.fr; or Mark R. Palmert, MD, PhD, Hospital for Sick Children, Division of Endocrinology, 555 University Ave, Toronte, Ontario, Canada M5G 1X8. E-mail: mark. palmert@sickkids.ca

PEDIATRICS (ISSN Numbers: Print, 0031-4005; Online, 1098-4275). Copyright $\odot 2009$ by the American Academy of Pediatrics

\footnotetext{
G ONADOTROPIN-RELEASING HORMONE ANALOGS (GnRHas) are standard of care for treatment of central precocious Tuberty (CPP). However, despite a favorable record of safety and efficacy, significant questions remain regarding their use. The European Society for Pediatric Endocrinology (ESPE) and the Lawson Wilkins Pediatric Endocrine Society (LWPES) convened a consensus conference to examine GnRHa therapy in pediatric patients. We did not address whether historically defined normal ages for the onset of puberty should be modified but used the
} 
operational definition of precocious puberty as puberty beginning before 8 years of age in girls and 9 years of age in boys.

\section{METHODS}

\section{Participant Selection}

Consideration was given to equal representation from North America (United States and Canada) and Europe, an equal male/female ratio, and a balanced spectrum of professional seniority and expertise.

\section{Process}

Thirty participants were put into 1 of 6 groups with assigned topics and designated chairpersons. Each participant prepared a summary of the literature regarding a question that was distributed before the conference (held over 3 days in November 2007). Each group revised the summaries and presented them to the full conference. If consensus could not be reached, conclusions were made on the basis of a vote of all participants. This report is organized around the questions that were addressed; it has been approved by the participants and endorsed by the LWPES and ESPE.

\section{Evaluation of Evidence}

Preference was given to articles written in English with long-term outcome data published between 1990 and 2007. The US Public Health grading system ${ }^{1}$ was used to grade the evidence and strength of the recommendations.* Grading was reviewed by the full conference under the guidance of a methodologist/biostatistician. This report is a not a practice guideline; nonetheless, we aimed to adhere to modified appraisal of guidelines research and evaluation (AGREE) criteria. $^{2}$

\section{INITIATION OF GnRHa THERAPY FOR CPP}

\section{Clinical Criteria}

The most important clinical criterion for GnRHa treatment is documented progression of pubertal development, which is based on the recognition that many patients with CPP have a slowly progressive or nonprogressive form and achieve adult height $(\mathrm{AH})$ within their target range without GnRHas. ${ }^{3-7}$ Accelerated growth velocity and skeletal maturation are other features of sustained and/or rapidly progressing CPP. ${ }^{8}$ However, some patients with slowly progressive CPP and advanced bone age (BA) reach normal $\mathrm{AH}$ without intervention. ${ }^{3}$

Conclusions: Progressive pubertal development and growth acceleration should be documented over a 3- to 6-month period before GnRHa therapy. This observational period may not be necessary if the child is at or past Tanner stage III (breast), particularly with advanced skeletal maturation (CIII).

\footnotetext{
*The qualities of evidence are I (data from $\geq 1$ properly randomized, controlled trial), II (data from other clinical studies), and III (data from opinions of respected authorities based on clinical experience, descriptive studies, or reports of expert committees), and the strengths of recommendation are $\mathrm{A}$ (good evidence to support use), B (moderate evidence to support use), C (poor evidence to support recommendation), D (moderate evidence against use), and $E$ (strong evidence against use)
}

\section{Chronological Age and Psychosocial Criteria}

Common reasons for GnRHa therapy are potential for compromise in adult stature, inability to adapt oneself to menarche, and psychosocial difficulties. Most of the evidence concerns height outcomes (predicted versus actual $\mathrm{AH}$ ) and age at initiation of therapy, but no randomized, controlled trials quantifying the effect of therapy on $\mathrm{AH}$ are available. The Bayley-Pinneau method is commonly used to predict $\mathrm{AH}$ and is likely better than other prediction methods'; however, in some instances, it may overpredict height by several centimeters. ${ }^{10,11}$

The greatest height gain has been observed in girls with onset of puberty at $<6$ years (average gain $9-10$ $\mathrm{cm}$, but with variation among studies $\left.{ }^{6,12-16}\right)$. Girls with onset between 6 and 8 years comprise a heterogeneous group that may have a moderate benefit ranging from $4.5 \pm 5.8^{13}$ to $7.2 \pm 5.3 \mathrm{~cm} .{ }^{6}$ Insufficient data exist to relate CA to height outcomes among boys. ${ }^{17}$

Data regarding the psychosocial impact of untreated or treated CPP are inconclusive, and whether delaying puberty with GnRHas may improve social functioning is still an open question. Early menarche in the general population is associated with risk-taking behavior, ${ }^{18}$ but it is unclear whether such data can be generalized to CPP. In patients with severe developmental delay, CPP may be associated with inappropriate behavior. If suppression of menses is the primary goal, GnRHas are only one of several therapeutic options, including progestogens, that could be considered. ${ }^{19}$

Conclusions: Girls with onset of progressive CPP before 6 years of age benefit most in terms of height from GnRHas. The decision to initiate therapy in girls with onset after the age of 6 should be individualized (BII). Treatment should be considered for all boys with onset of progressive CPP before 9 years of age who have compromised height potential (CIII). The use of GnRHas solely to influence the psychosocial consequences of CPP or to delay menarche should be considered carefully given the absence of convincing data (CIII). Additional studies to evaluate the effects of GnRHa therapy on quality of life and psychosocial functioning are needed.

\section{Adopted Children}

Boys and girls adopted internationally are at risk of CPP, although data are limited for boys. ${ }^{20,21}$ Response to GnRHas in adopted girls with precocious or early normal puberty seems comparable with that seen in nonadopted girls. ${ }^{22}$ Adopted children may be at increased risk of emotional and behavioral problems, ${ }^{23}$ but no data are available to demonstrate that GnRHa therapy improves psychological well-being. ${ }^{24}$

Conclusions: Although international adoption constitutes a risk factor for CPP, adopted children should be treated no differently than nonadopted children with CPP (CIII).

\section{Hormonal Criteria}

Luteinizing hormone (LH) measurements are the most valuable biochemical parameter for the diagnosis of CPP. 


\begin{tabular}{|c|c|c|c|c|}
\hline & Rapid Acting & Monthly Depot & 3-mo Depot & 12-mo Implant \\
\hline Dosing & $\begin{array}{c}\text { 3-4 times daily (intranasal) or } \\
\text { every day (subcutaneous) }\end{array}$ & Every $28 \mathrm{~d}$ & Every $90 \mathrm{~d}$ & Every year \\
\hline $\begin{array}{l}\text { Peak serum } \\
\text { concentrations }\end{array}$ & $10-45 \min$ & $4 \mathrm{~h}$ & $4-8 \mathrm{~h}$ & $1 \mathrm{mo}$ \\
\hline $\begin{array}{l}\text { Onset of therapeutic } \\
\text { suppression }\end{array}$ & $2-4 w k$ & $1 \mathrm{mo}$ & $1 \mathrm{mo}$ & $1 \mathrm{mo}$ \\
\hline Advantage & Quick on/off & Dosing and efficacy well studied & $\begin{array}{l}\text { Fewer injections and fewer } \\
\text { compliance concerns }\end{array}$ & No injections needed \\
\hline Disadvantage & $\begin{array}{l}\text { Multiple daily doses needed/ } \\
\text { compliance very difficult }\end{array}$ & $\begin{array}{l}\text { Painful injections/suboptimal } \\
\text { compliance }\end{array}$ & Painful injection & $\begin{array}{l}\text { Requires surgical procedure for } \\
\text { insertion and removal }\end{array}$ \\
\hline
\end{tabular}

Because prepubertal LH levels are $<0.1 \mathrm{IU} / \mathrm{L}, \mathrm{LH}$ assays used should have a detection limit near $0.1 \mathrm{IU} / \mathrm{L} .{ }^{25-27} \mathrm{In}$ 1 study of normal children, basal LH levels distinguished prepubertal (LH $<0.2 \mathrm{IU} / \mathrm{L}$ ) and pubertal males with $100 \%$ sensitivity and specificity, but $50 \%$ of the girls with Tanner stage 2 breasts had levels in the prepubertal range. ${ }^{27}$

LH can be measured after stimulation with GnRH (single serum sample at 30-40 minutes ${ }^{27-29}$ ) or with a GnRHa such as aqueous leuprolide (single sample at 60 minutes ${ }^{30,31}$ ). Peak LH values show an overlap between prepubertal and early pubertal children. As with basal LH, variability among assays and paucity of normative data have hampered the development of diagnostic cutoffs for CPP, although an (assay-specific) prepubertal limit of peak LH at 3.3 to $5.0 \mathrm{IU} / \mathrm{L}$ has been suggested. $25,27,28$

LH levels provide more information than those of follicle-stimulating hormone (FSH). However, the stimulated LH/FSH ratio may help differentiate progressive CPP (which tends to have higher LH/FSH ratios) from nonprogressive variants that do not require GnRHa therapy. ${ }^{32-34}$

For estradiol, the most sensitive measurements (tandem mass spectrometry) have shown that prepubertal levels may be $<1 \mathrm{pg} / \mathrm{mL}$ ( $3.7 \mathrm{pmol} / \mathrm{L}$ ) and undetectable with commonly available assays. ${ }^{35}$ Thus, in non-mass spectrometry assays, measurable estradiol only confirms relatively advanced puberty. Similarly, testosterone assays with detection limits of $>10 \mathrm{ng} / \mathrm{dL}$ may not discriminate prepubertal from early pubertal levels. ${ }^{36}$ For estradiol and testosterone, the laboratory used must have a defined prepubertal range.

Conclusions: Sensitive assays with pediatric norms should be used and stimulation results interpreted depending on the agent used (BII). The same caveats are important if hormonal testing is used to monitor therapy (see below). Basal LH levels are useful screening tests and may be diagnostic (BII). Stimulated LH levels are important, but interpretation suffers from assay variability and absence of clear diagnostic cutoffs (BII). Gonadal sex-steroid levels can add information in support of the diagnosis but are not sufficient (BII).

\section{Pelvic Ultrasound}

Female patients with CPP have increased ovarian and uterine dimensions compared with prepubertal controls and girls with premature thelarche. ${ }^{37}$ For CPP, cutoff values for uterine length range from 3.4 to $4.0 \mathrm{~cm}$. The presence of an endometrial echo is highly specific $(\sim 100 \%)$ but less sensitive $(42 \%-87 \%) .{ }^{34}$ The cutoffs for a pubertal ovarian volume range between 1 and $3 \mathrm{~mL}$ $($ volume $=$ length $\times$ width $\times$ height $\times 0.5233) .{ }^{38}$

Conclusions: Pelvic ultrasound is helpful in differentiating CPP from premature thelarche as an adjunct to GnRH stimulation (BII).

\section{Central Nervous System Imaging}

CPP may be a sign of central nervous system pathology. Unsuspected intracranial pathology has been reported in $8 \%$ of girls ${ }^{39,40}$ and $40 \%$ of boys ${ }^{41}$ without neurologic findings or neurofibromatosis. The percentage of children with unsuspected intracranial pathology decreases with age. ${ }^{39-41}$ Only $2 \%$ to $7 \%$ of girls who have onset of CPP between the ages of 6 and 8 years have unsuspected pathology, and only $\sim 1 \%$ have a tumor such as a glioma or astrocytoma. ${ }^{39,40}$ Factors that may decrease the likelihood of finding a tumor include racial/ethnic background, family history of CPP, and adoption.

Conclusions: All boys with CPP and girls with CPP at $<6$ years of age should have a head MRI. It is controversial whether all girls who develop CPP between 6 and 8 years of age require head MRI. Girls with neurologic findings and rapid pubertal progression are more likely to have intracranial pathology and require an MRI examination (BII).

\section{AVAILABLE GnRHas AND THERAPEUTIC REGIMENS FOR CPP}

\section{Currently Available Therapeutic Regimens}

All available GnRHas are effective despite their different routes of administration, dosing, and duration of action (Tables 1-3). ${ }^{42,43}$ The depot preparations are preferred be-

\section{TABLE 2 Rapid-Acting Formulations of GnRHa}

\begin{tabular}{llr}
\hline GnRHa & Administration & Starting Dose, per day \\
\hline Nafarelin & Nasal spray & $800 \mu \mathrm{g}$ twice \\
Buserelin & Nasal spray & $20-40 \mu \mathrm{g} / \mathrm{kg}$ \\
Buserelin & Subcutaneous & $1200-1800 \mu \mathrm{g}$ \\
Leuprolide & Subcutaneous & $50 \mu \mathrm{g} / \mathrm{kg}$ \\
Deslorelin & Subcutaneous & $4-8 \mu \mathrm{g} / \mathrm{kg}$ \\
Histrelin & Subcutaneous & $8-10 \mu \mathrm{g} / \mathrm{kg}$ \\
Triptorelin & Subcutaneous & $20-40 \mu \mathrm{g} / \mathrm{kg}$ \\
\hline
\end{tabular}




\begin{tabular}{|c|c|c|}
\hline $\begin{array}{l}\text { Depot } \\
\text { Preparation }\end{array}$ & Brand Name & Starting Dose \\
\hline Goserelin & Zoladex LA & $\begin{array}{l}3.6 \mathrm{mg} \text { every month or } 10.8 \mathrm{mg} \\
\text { every } 3 \mathrm{mo}\end{array}$ \\
\hline Buserelin & Suprefact depot & $6.3 \mathrm{mg}$ every $2 \mathrm{mo}$ \\
\hline \multirow[t]{3}{*}{ Leuprolide } & $\begin{array}{l}\text { Enantone or } \\
\text { Lupron-depot }\end{array}$ & $\begin{array}{l}3.75 \mathrm{mg} \text { every month or } 11.25 \\
\mathrm{mg} \text { every } 3 \mathrm{mo}\end{array}$ \\
\hline & Prostap SR & $3.75 \mathrm{mg}$ every month \\
\hline & Lupron depot PED & $\begin{array}{l}\text { 7.5, } 11.25, \text { or } 15 \mathrm{mg} \text { every month } \\
(0.2-0.3 \mathrm{mg} / \mathrm{kg} \text { per mo) or } \\
11.25 \mathrm{mg} \text { every } 3 \mathrm{mo}^{\mathrm{a}}\end{array}$ \\
\hline Triptorelin & $\begin{array}{l}\text { Decapeptyl, } \\
\text { Gonapeptyl }\end{array}$ & $\begin{array}{c}3 \text { or } 3.75 \mathrm{mg} \text { every month or } \\
11.25 \mathrm{mg} \text { every } 3 \mathrm{mo}\end{array}$ \\
\hline Histrelin & Supprelin LA & $50 \mathrm{mg}$ implant every year \\
\hline
\end{tabular}

a No data are available on the use of the 22.5-mg 3-month depot in children.

cause of improved compliance. ${ }^{44-46}$ In most children, monthly injections adequately suppress the gonadotropic axis, but some children require more frequent injections or higher-than-standard doses. The 3-month formulations are comparable with monthly dosing, but no randomized comparative trial is available. ${ }^{42,47-49}$ In 1 prospective trial, $7.5 \mathrm{mg}$ of leuprolide monthly suppressed LH more effectively than $11.25 \mathrm{mg}$ every 3 months, although sex-steroid concentrations were equally inhibited. ${ }^{50}$ The 50 -mg histrelin-acetate implant provides sustained suppression for 12 months. ${ }^{51,52}$

Conclusions: A variety of GnRHa formulations are available and efficacious. The choice of a particular agent depends on patient and physician preference and on local marketing approval (CIII).

\section{Treatment Monitoring}

Progression of breast or testicular development is suggestive of treatment failure, ${ }^{52-56}$ but progression of pubic hair may indicate normal adrenarche. Growth velocity, height SD score (SDS), and BA advancement should decline during treatment. Vaginal bleeding may occur after the first administration of GnRHas, but subsequent bleeding suggests lack of efficacy or incorrect diagnosis. Markedly decreased growth velocity (less than or equal to a -2 SDS) or rapid BA advancement should also prompt reassessment. BA can be used to update $\mathrm{AH}$ prediction understanding that the Bayley-Pinneau method may overestimate AH. ${ }^{57}$ If elevated, random LH levels obtained by using an ultrasensitive assay indicate lack of suppression. Stimulated LH values (using GnRH, aqueous GnRHas, or the free GnRHas contained in depot preparations) can also be used to assess effectiveness. FSH levels are not normally used to monitor suppression. If measured, testosterone and estradiol levels should be in a prepubertal range for the assay used. ${ }^{44,51,53-}$ 56,58 No long-term data have provided compelling support for any specific short-term monitoring scheme.

Conclusions: GnRHa-injection dates should be recorded and adherence with the dosing interval monitored (BII). Tanner stage and growth should be assessed every 3 to 6 months, and BA should be monitored periodically (BII). There was no consensus about the routine use of random or stimulated measurements of gonadotropins or sex steroids for monitoring therapy. For patients with suboptimal clinical response, there was consensus about need for comprehensive reassessment (CIII). Additional information on the relationship between on-treatment measures of gonadotropic axis suppression and outcomes are needed.

\section{Adverse Events}

GnRHas are generally well tolerated in children and adolescents. Systemic complaints such as headaches or hot flashes occur occasionally but are usually short-term and do not interfere with therapy. Local adverse events occur in $\sim 10 \%$ to $15 \%$ of patients and necessitate a change in agent when persistent, because they can result in sterile abscesses in a fraction of the patients. ${ }^{54,55,59}$ Although exceedingly rare, anaphylaxis has been described.

\section{Potential New Therapeutic Agents for the Treatment of CPP}

$\mathrm{GnRH}$ antagonists cause immediate and direct inhibition at the level of pituitary GnRH receptors. ${ }^{60}$ Theoretical advantages over GnRHas include eliminating the initial "flare" in gonadotropic axis activation and rapid recovery of suppression once therapy is withdrawn. Depot and nonpeptide orally active GnRH antagonists are under development ${ }^{61}$ and could be evaluated in children with CPP in the future.

\section{Therapeutic Agents That Can Be Combined With GnRHas for the Treatment of CPP}

Adjunctive therapies that may improve outcomes $(\mathrm{AH}$, for example) of GnRHa therapy include pure or selective estradiol estrogen receptor blockers, aromatase inhibitors, ${ }^{62}$ pure antiandrogens, sex steroids, ${ }^{63}$ or nonaromatizable anabolic steroids. ${ }^{64}$ The addition of oxandrolone increased AH compared with GnRHas alone in a small $(n=10)$ nonrandomized study. ${ }^{64}$ The addition of growth hormone $(\mathrm{GH})$ increased $\mathrm{AH}$ compared with GnRHas alone in girls with CPP and slow growth velocity in small ( $n=10$ and 17) nonrandomized series. ${ }^{65,66}$ The addition of GH increased height outcome in a randomized, controlled study $(n=46)$ of adopted girls with precocious or early puberty. ${ }^{22}$ However, to date, no large-scale randomized, controlled trials evaluating the addition of $\mathrm{GH}$ to GnRHas for CPP have been performed.

Conclusions: The addition of GH or oxandrolone to GnRHas cannot be routinely recommended. These adjunctive therapies require validation by larger studies with consideration for potential adverse effects (CIII).

\section{DISCONTINUATION OF GnRHa THERAPY IN CPP}

Factors that could influence the decision to stop GnRHa treatment depend on the primary goal(s) of therapy, including maximizing height, synchronizing puberty with peers, ameliorating psychological distress, and facilitating care of the developmentally delayed child. Available data only permit analysis of factors that affect AH among girls. 


\section{Treatment Duration}

Several studies have reported a direct relationship between treatment duration and $\mathrm{AH}^{14,15,67-69}$ and an inverse relationship between age at pubertal onset or at initiation of therapy and AH. ${ }^{6,14,67-69}$ However, deciphering the respective influences of age at onset of puberty, age at initiation of therapy, and treatment duration is problematic, because these variables are interrelated. Undue delay in initiation of therapy (>1-2 years) may compromise $\mathrm{AH}$

Parent/Patient Preference, Anticipated Time of Menarche, CA, and $\mathrm{BA}$

In the studies we examined, wishes of the patient and family and the physician's decision were stated as deciding factors for cessation of treatment. ${ }^{13,15,68,70-73}$ The mean age at treatment discontinuation ranged from 10.6 to 11.6 years, with mean BA ranging from 12.1 to 13.9 years and mean age at menarche of $\sim 12.3$ years. Discontinuation at a CA of $\sim 11.0$ years $^{13}$ and a BA of $\sim 12.0$ years $^{14,67}$ has been associated with maximum AH. However, BA is not an appropriate single variable, because a BA of $\sim 12.0$ years can be observed at different CAs and because BA is unreliable for predicting height gain after treatment. ${ }^{12-15,72}$ One study has suggested that height gain after treatment may be higher for those with early $\left(<6\right.$ years) versus late treatment. ${ }^{6}$

\section{Height and Growth Velocity}

Although growth velocity during therapy, 13-15,67-69,71,72 and height at interruption of therapy are positively associated with $\mathrm{AH}, 6,13,14$ they cannot be used as independent factors for deciding when to stop treatment. For a child with unexplained marked deceleration of growth, consideration might be given to stopping treatment or to introducing adjunct therapies.

Conclusions: There is insufficient evidence to rely on any one clinical variable (CA, duration of therapy, BA, height, target height, growth velocity) to make the decision to discontinue treatment (CIII). Therefore, it is reasonable to consider these parameters and informed parent and patient preferences, with the goal of menarche occurring near the population norms (CIII).

\section{OUTCOMES OF GnRHa THERAPY FOR CPP}

\section{Reproductive Function}

Follow-up studies have been performed with girls in their late teens ${ }^{68,69,74-76}$ and women up to 31 years in 1 study 77 and have reported that ovarian function was not impaired. ${ }^{68,69,74,75,78,79}$ Menses began 2 to 61 months (mean: $\sim 16$ months) after the end of treatment. ${ }^{69,74-77}$ Regular ovarian cycles occurred in $60 \%$ to $96 \%$ of the patients, without differences from reference populations. ${ }^{69,74-77}$ Infertility has not been reported. Of 28 reported pregnancies, ${ }^{69,74,75,77} 7$ were terminated and 21 resulted in healthy children. ${ }^{69,75,77}$ Three small studies showed no differences from controls in gonadal function for boys at the ages of 15 to 18 years. ${ }^{68,78,79}$ Paternity rates have not been reported.

Conclusions: The available data suggest that gonadal function is not impaired in girls treated with GnRHas (BII). Nevertheless, available data are limited. Long-term data on fecundity and ovarian reserve of treated patients with CPP are needed.

\section{BMI and Correlates of Metabolic Syndrome}

Childhood obesity is associated with earlier pubertal development in girls, and early sexual maturation is associated with increased prevalence of overweight and obesity. There has been concern that GnRHa therapy may affect BMI. Eleven studies addressed BMI outcome in girls with CPP, $, 12,49,69,75,80-852$ included boys, ${ }^{78,80}$ and 1 included girls with early puberty (onset at the ages of 8 and 9 years). ${ }^{86}$ Before GnRHa treatment, mean BMI SDS was above average in girls with CPP in all studies, whereas results were split in boys. ${ }^{78,80}$ The combined analysis indicates that BMI SDS did not increase after treatment irrespective of age at presentation. At $\mathrm{AH}$, mean BMI SDS ranged from 0.1 to 1.7 , with an overall slight decrease from pretreatment BMI. No reports regarding metabolic syndrome and GnRHa treatment were identified.

Conclusions: Above-average BMI is frequent at diagnosis of CPP. Long-term GnRHa treatment does not seem to cause or aggravate obesity, as judged from BMI (BII). Studies of body composition and fat distribution are needed.

\section{Bone Mineral Density}

Bone mineral density (BMD) may decrease during GnRHa therapy. However, subsequent bone mass accrual is preserved, and peak bone mass does not seem to be negatively affected by treatment. ${ }^{12,82,87}$ There is some suggestion that discontinuation of treatment in girls with a BA of $\leq 11.5$ years may lead to greater $\mathrm{BMD}^{87}$ and that, as in all adolescents, optimum calcium and vitamin D intake and skeletal-loading exercise may positively influence bone mass. ${ }^{82}$

Conclusions: Young adults treated with GnRHas for CPP in childhood ultimately accrue BMD within the normal range for age (BII).

\section{Risk of Polycystic Ovarian Syndrome}

The possibility that CPP is a first manifestation of polycystic ovarian syndrome (PCOS) has been raised. ${ }^{88}$ PCOS occurred in $0 \%$ to $12 \%$ of girls with CPP followed prospectively ${ }^{12,89-91}$ compared with $5 \%$ to $10 \%$ in the general population. ${ }^{92}$ Single studies have reported (1) an increased average ovarian size after CPP resulting from hypothalamic hamartoma, ${ }^{75}$ (2) a higher prevalence of exaggerated adrenarche in patients with CPP than in controls, ${ }^{93}$ and (3) the occurrence of signs of PCOS 0.5 to 4.0 years after menarche. ${ }^{94}$

Conclusions: Follow-up of treated or untreated girls with CPP into the midteenage years suggests that the development of PCOS (BII) or polycystic ovary morphology (CIII) is not clearly different from that in the general population. Premature adrenarche and early childhood insulin resistance are potential risk factors for PCOS, but it is not clear if the presence of these conditions along 
with CPP increases the eventual risk of PCOS (CIII). Longitudinal data through adolescence are needed.

\section{PSYCHOSOCIAL DEVELOPMENT}

Potential psychological consequences of CPP, including risk for emotional distress and problem behavior, are often used to justify treatment with GnRHas.95,96 Hormonally induced behavioral changes (eg, aggression, sexuality) that occur during normal puberty ${ }^{97}$ may occur earlier in children with CPP, perhaps consistent with the hormonal effects on brain development observed in rodents..$^{98}$

Limited data are available regarding psychological consequences of CPP, and the few existing studies have limitations that have yielded inconsistent conclusions. ${ }^{99}$ In 2 studies examining psychological functioning in girls with CPP before and after treatment, ${ }^{24,100}$ no consistent patterns of change were observed. GnRHas have been suggested to adversely affect mood and cognition in adults, ${ }^{101}$ but similar effects have not been evaluated in children.

Conclusions: There is little evidence to show whether CPP leads to psychological or behavioral problems or whether treatment with GnRHas are associated with improved psychological outcome (CIII). Thus, no recommendations related to psychosocial outcomes are possible. Controlled studies with standardized instruments are needed.

\section{USE OF GnRHas FOR CONDITIONS OTHER THAN CPP}

\section{Gonadal Protection for Children Undergoing Chemotherapy}

Infertility represents one of the main long-term consequences of chemotherapy. Studies that evaluated the effects of ovarian suppression by GnRHas during chemotherapy in adult and adolescent patients have yielded inconsistent results. ${ }^{102-104}$ Prospective, randomized trials in adult women are ongoing (see NCT00196846, NCT0090844, NCT00380406, NCT00068601 at http:// clinicaltrials.gov/).

Conclusions: Routine use of GnRHas for gonadal protection in children undergoing chemotherapy cannot be suggested (CIII).

\section{Increasing AH of Children With Idiopathic Short Stature}

The effect of GnRHa therapy on AH has been evaluated in girls with idiopathic short stature (ISS) and normal puberty ( $8-10$ years of age), with a mean gain compared with predicted height of 0 to $4.2 \mathrm{~cm}$. + In boys with rapidly progressing puberty, GnRHa therapy increased AH compared with predicted height. ${ }^{5}$ The effects of combined GH and GnRHa therapy in children with ISS are controversial, ${ }^{111}$ with mean gains of 4.4 to $10 \mathrm{~cm}$ with combination therapy versus -0.5 to $6.1 \mathrm{~cm}$ in untreated controls. ${ }^{112,113}$ In these studies, one cannot definitively separate the effects of GH from GnRHas. In 2 randomized studies of adopted girls with normal puberty, GnRHas plus GH was compared with GnRHas alone, with a $3-\mathrm{cm}$ height gain demonstrated with combination ther-

†Refs $6,14,15,57,69,71,73$, and 105-110. apy. ${ }^{22,114}$ Disadvantages of the use of GnRHas in children with ISS include absence of pubertal growth acceleration, delayed puberty with potential psychosocial disadvantage, and decreased BMD. Long-term follow-up studies are lacking.

Conclusions: GnRHa therapy alone in children with ISS and normally timed puberty is minimally effective in increasing $\mathrm{AH}$, may compromise $\mathrm{BMD}$, and cannot be suggested for routine use (DII). Combined GnRHa and GH therapy leads to a significant height gain but may have adverse effects. Routine use of GnRHas in children with ISS being treated with GH cannot be suggested (CIII).

\section{Increasing AH of Children Born Small for Gestational Age}

Short children born small for gestational age (SGA) usually have a normal pubertal timing, although some of them have rapidly progressing puberty, and may be treated with GH. ${ }^{92,115}$ Data on the additional effect of GnRHas are limited. ${ }^{113}$

Conclusions: Routine use of the combination of $\mathrm{Gn}$ RHas and GH in children born SGA cannot be suggested (CIII).

\section{Increasing AH of Children With Severe Hypothyroidism}

Some children with severe hypothyroidism are at risk for rapid progression through puberty and diminished $\mathrm{AH}$. In the only study available, combined GnRHas and levothyroxine and levothyroxine alone produced similar gains in height SDS. ${ }^{116}$

Conclusions: Routine use of combined therapy with GnRH and levothyroxine cannot be suggested (CIII).

\section{Increasing AH of Children With GH Deficiency}

Some children with GH deficiency are short at the start of puberty and at risk for short adult stature. Retrospective studies that evaluated the addition of GnRHas to GH involved a limited number of subjects and provided controversial results. ${ }^{117-119}$ Three prospective studies that reported near-AH or AH have shown an $\sim$ l-SD height gain, ${ }^{120-122}$ possibly without detrimental effect on BMD. ${ }^{123}$

Conclusions: Routine use of combined therapy with $\mathrm{GnRH}$ and GH in GH-deficient children with low predicted $\mathrm{AH}$ at onset of puberty cannot be suggested (CIII).

\section{Increasing AH of Children With Congenital Adrenal Hyperplasia}

One nonrandomized study examined the effect of combined GH and GnRHa treatment on $\mathrm{AH}$ in 14 children with congenital adrenal hyperplasia $(\mathrm{CAH})$ and normal or precocious puberty and found a l-SD increase in $\mathrm{AH}$ in comparison with standard treatment for CAH. ${ }^{124}$

Conclusions: Additional studies are needed to determine if GnRHa therapy alone or in combination with GH should be used in children with $\mathrm{CAH}$ and low predicted $\mathrm{AH}$. Routine use of GnRHas for CAH cannot be suggested (CIII).

\section{Children With Autism}

Conclusions: Despite 1 controversial article reporting that GnRHas may benefit behavioral symptoms in chil- 
dren with autism, ${ }^{125}$ the consensus is that there is no current evidence for GnRHa therapy for this indication (CIII).

\section{CONCLUSIONS}

Several important observations emerged from this conference. Despite a considerable body of literature on the use of GnRHas, few rigorously conducted and controlled prospective studies are available from which to derive evidence-based recommendations. Most of our conclusions are categorized as CIII, a level of evidence that underscores the need for additional research in key areas such as the psychosocial effects of GnRHa treatment for $\mathrm{CPP}$. The efficacy in increasing $\mathrm{AH}$ is undisputed only in early-onset progressive CPP, which highlights the need to increase our knowledge of the pathophysiology and normal limits of puberty and of the physical and psychosocial consequences of treated and untreated CPP. Our systematic review also highlighted the lack of objective support for commonly voiced concerns such as the propensity for GnRHas to promote weight gain or to lead to long-term diminution of BMD. Use of GnRHas for conditions other than CPP requires additional investigation and cannot be routinely suggested.

\section{ACKNOWLEDGMENTS}

Each participant to the conference provided a conflictof-interest disclosure that is available on request. A portion of the funding for the conference was provided by pharmaceutical companies that produce and market GnRH agonists (Ferring, Indevus, Ipsen, TAP). Representatives from these companies did not participate in any deliberations, did not contribute to the content of the report, and did not review or comment on the report before publication.

The following are members of the ESPE-LWPES GnRH Analogs Consensus Conference Group (in alphabetical order, with group chairs indicated by an asterisk) and are considered coauthors of this article: Franco Antoniazzi (Pediatric Clinic, Policlinico Giambattista Rossi, University of Verona, Verona, Italy); Sheri Berenbaum (Departments of Psychology and Pediatrics, Pennsylvania State University, University Park, PA); Jean-Pierre Bourguignon (Department of Pediatrics, University of Liège, Liège, Belgium); George P. Chrousos (First Department of Pediatrics, University of Athens, Athens, Greece); Joël Coste (Department of Biostatistics, Groupe Hospitalier Cochin-Saint Vincent de Paul and Université Paris-Descartes, Paris, France); Cheri Deal* (Endocrine Service, Sainte-Justine Hospital Research Center, University of Montreal, Montreal, Quebec, Canada); Liat de Vries (Institute for Endocrinology and Diabetes, Schneider Children's Medical Center of Israel, Petah-Tikva, Israel, and Sackler School of Medicine, Tel-Aviv University, Tel-Aviv, Israel); Carol Foster (Department of Pediatrics/Endocrinology, University of Utah, Salt Lake City, UT); Sabine Heger, Children's Hospital Auf der Bult, Hanover, Germany); Jack Holland (McMaster Children's Hospital, McMaster University, Hamilton, Ontario, Canada); Kirsi Jahnukainen (Pediatric Endocrinology Unit,
Department of Woman and Child Health, Karolinska Institute, Stockholm, Sweden, and Department of Pediatrics, University of Turku, Turku, Finland); Anders Juul* (Department of Growth and Reproduction, Rigshospitalet, University of Copenhagen, Copenhagen, Denmark); Paul Kaplowitz (Chief of Endocrinology, Children's National Medical Center, George Washington University School of Medicine, Washington, DC); Najiba Lahlou (Department of Pediatric Hormonology and Metabolic Diseases, CHU Cochin-Saint Vincent de Paul, Paris, France); Mary M. Lee (Pediatric Endocrine Division, University of Massachusetts Medical School, Worcester, MA); Peter Lee (Section of Pediatric Endocrinology, Department of Pediatrics, Riley Hospital for Children, Indiana University School of Medicine, Indianapolis, IN, and Penn State College of Medicine, Milton S. Hershey Medical Center, Hershey, PA); Deborah P. Merke* (National Institutes of Health Clinical Center and Reproductive Biology and Medicine Branch, Eunice Kennedy Shriver Eunice Kennedy Shriver National Institute of Child Health and Human Development, National Institutes of Health, Bethesda, MD); E. Kirk Neely* (Division of Pediatric Endocrinology and Diabetes, Stanford University, Stanford, CA); Wilma Oostdijk (Department of Pediatrics, Leiden University Medical Center, Leiden, Netherlands); Moshe Phillip* (Institute for Endocrinology and Diabetes, Schneider Children's Medical Center of Israel, Petah-Tikva, Israel, and Sackler School of Medicine, Tel-Aviv University, Tel-Aviv, Israel); Robert L. Rosenfield* (University of Chicago Pritzker School of Medicine, Departments of Pediatrics and Medicine, Section of Pediatric Endocrinology, University of Chicago Comer Children's Hospital, Chicago, IL); Dorothy Shulman (Department of Pediatrics, All Children's Hospital/University of South Florida, Tampa, FL); Dennis Styne (Rumsey Chair of Pediatric Endocrinology, Professor of Pediatrics, University of California, Sacramento, CA); Maïthé Tauber (Unité d’Endocrinologie, Hôpital des Enfants, Toulouse, France); and Jan M. Wit (Department of Pediatrics, Leiden University Medical Center, Leiden, Netherlands.

We acknowledge Dr Christina Kanaka-Gantenbein (First Department of Pediatrics, University of Athens, Athens, Greece) for her help to Prof George P. Chrousos in the preparation of his contribution to the meeting.

\section{REFERENCES}

1. Kish MA. Guide to development of practice guidelines. Clin Infect Dis. 2001;32(6):851-854

2. AGREE Collaboration. Development and validation of an international appraisal instrument for assessing the quality of clinical practice guidelines: the AGREE project. Qual Saf Health Care. 2003;12(1):18-23

3. Palmert MR, Malin HV, Boepple PA. Unsustained or slowly progressive puberty in young girls: initial presentation and long-term follow-up of 20 untreated patients. J Clin Endocrinol Metab. 1999;84(2):415-423

4. Klein KO. Precocious puberty: who has it? Who should be treated? J Clin Endocrinol Metab. 1999;84(2):41 1-414

5. Lazar L, Pertzelan A, Weintrob N, Phillip M, Kauli R. Sexual precocity in boys: accelerated versus slowly progressive pu- 
berty gonadotropin-suppressive therapy and final height. $J$ Clin Endocrinol Metab. 2001;86(9):4127-4132

6. Lazar L, Padoa A, Phillip M. Growth pattern and final height after cessation of gonadotropin-suppressive therapy in girls with central sexual precocity. J Clin Endocrinol Metab. 2007; 92(9):3483-3489

7. Fontoura M, Brauner R, Prevot C, Rappaport R. Precocious puberty in girls: early diagnosis of a slowly progressing variant. Arch Dis Child. 1989;64(8):1170-1176

8. Papadimitriou A, Beri D, Tsialla A, Fretzayas A, Psychou F, Nicolaidou P. Early growth acceleration in girls with idiopathic precocious puberty. J Pediatr. 2006;149(1):43-46

9. Zachmann M, Sobradillo B, Frank M, Frisch H, Prader A. Bayley-Pinneau, Roche-Wainer-Thissen, and Tanner height predictions in normal children and in patients with various pathologic conditions. J Pediatr. 1978;93(5):749-755

10. Bar A, Linder B, Sobel EH, Saenger P, DiMartino-Nardi J. Bayley-Pinneau method of height prediction in girls with central precocious puberty: correlation with adult height. J Pediatr. 1995;126(6):955-958

11. Kauli R, Galatzer A, Kornreich L, Lazar L, Pertzelan A, Laron Z. Final height of girls with central precocious puberty, untreated versus treated with cyproterone acetate or GnRH analogue: a comparative study with re-evaluation of predictions by the Bayley-Pinneau method. Horm Res. 1997;47(2): 54-61

12. Heger S, Partsch CJ, Sippell WG. Long-term outcome after depot gonadotropin-releasing hormone agonist treatment of central precocious puberty: final height, body proportions, body composition, bone mineral density, and reproductive function. J Clin Endocrinol Metab. 1999;84(12):4583-4590

13. Carel JC, Roger M, Ispas S, et al. Final height after long-term treatment with triptorelin slow-release for central precocious puberty: importance of statural growth after interruption of treatment. J Clin Endocrinol Metab. 1999;84(6):1973-1978

14. Arrigo T, Cisternino M, Galluzzi F, et al. Analysis of the factors affecting auxological response to $\mathrm{GnRH}$ agonist treatment and final height outcome in girls with idiopathic central precocious puberty. Eur J Endocrinol. 1999;141(2):140-144

15. Klein KO, Barnes KM, Jones JV, Feuillan PP, Cutler GB Jr. Increased final height in precocious puberty after long-term treatment with LHRH agonists: the National Institutes of Health experience. J Clin Endocrinol Metab. 2001;86(10): $4711-4716$

16. Paul D, Conte FA, Grumbach MM, Kaplan SL. Long-term effect of gonadotropin-releasing hormone agonist therapy on final and near-final height in 26 children with true precocious puberty treated at a median age of less than 5 years. $J$ Clin Endocrinol Metab. 1995;80(2):546-551

17. Mul D, Bertelloni S, Carel JC, Saggese G, Chaussain JL, Oostdijk W. Effect of gonadotropin-releasing hormone agonist treatment in boys with central precocious puberty: final height results. Horm Res. 2002;58(1):1-7

18. Kaltiala-Heino R, Marttunen M, Rantanen P, Rimpelä $M$. Early puberty is associated with mental health problems in middle adolescence. Soc Sci Med. 2003;57(6):1055-1064

19. Albanese A, Hopper NW. Suppression of menstruation in adolescents with severe learning disabilities. Arch Dis Child. 2007;92(7):629-632

20. Teilmann G, Boas M, Petersen JH, et al. Early pituitarygonadal activation before clinical signs of puberty in 5- to 8 -year-old adopted girls: a study of 99 foreign adopted girls and 93 controls. J Clin Endocrinol Metab. 2007;92(7): $2538-2544$

21. Teilmann G, Pedersen CB, Skakkebaek NE, Jensen TK. Increased risk of precocious puberty in internationally adopted children in Denmark. Pediatrics. 2006;118(2). Available at: www.pediatrics.org/cgi/content/full/1 18/2/e391

22. Tuvemo T, Jonsson B, Gustafsson J, et al. Final height after combined growth hormone and GnRH analogue treatment in adopted girls with early puberty. Acta Paediatr. 2004;93(11): $1456-1462$

23. Berg-Kelly K, Eriksson J. Adaptation of adopted foreign children at mid-adolescence as indicated by aspects of health and risk taking: a population study. Eur Child Adolesc Psychiatry. 1997;6(4):199-206

24. Mul D, Versluis-den Bieman HJ, Slijper FM, Oostdijk W, Waelkens JJ, Drop SL. Psychological assessments before and after treatment of early puberty in adopted children. Acta Paediatr. 2001;90(9):965-971

25. Neely EK, Hintz RL, Wilson DM, et al. Normal ranges for immunochemiluminometric gonadotropin assays. J Pediatr. 1995;127(1):40-46

26. Neely EK, Wilson DM, Lee PA, Stene M, Hintz RL. Spontaneous serum gonadotropin concentrations in the evaluation of precocious puberty. J Pediatr. 1995;127(1):47-52

27. Resende EA, Lara BH, Reis JD, Ferreira BP, Pereira GA, Borges MF. Assessment of basal and gonadotropin-releasing hormone-stimulated gonadotropins by immunochemiluminometric and immunofluorometric assays in normal children. J Clin Endocrinol Metab. 2007;92(4):1424-1429

28. Roger M, Lahlou N, Chaussain JL. Gonadotropin-releasing hormone testing in pediatrics. In: Ranke MB, ed. Diagnostics of Endocrine Function in Children and Adolescents. Heidelberg, Germany: Johann Ambrosius Barth; 1996:346-369

29. Eckert KL, Wilson DM, Bachrach LK, et al. A single-sample, subcutaneous gonadotropin-releasing hormone test for central precocious puberty. Pediatrics. 1996;97(4):517-519

30. Garibaldi LR, Aceto T Jr, Weber C, Pang S. The relationship between luteinizing hormone and estradiol secretion in female precocious puberty: evaluation by sensitive gonadotropin assays and the leuprolide stimulation test. J Clin Endocrinol Metab. 1993;76(4):851-856

31. Ibáñez L, Potau N, Zampolli M, et al. Use of leuprolide acetate response patterns in the early diagnosis of pubertal disorders: comparison with the gonadotropin-releasing hormone test. J Clin Endocrinol Metab. 1994;78(1):30-35

32. Pescovitz OH, Hench KD, Barnes KM, Loriaux DL, Cutler GB Jr. Premature thelarche and central precocious puberty: the relationship between clinical presentation and the gonadotropin response to luteinizing hormone-releasing hormone. $J$ Clin Endocrinol Metab. 1988;67(3):474-479

33. Oerter KE, Uriarte MM, Rose SR, Barnes KM, Cutler GB Jr. Gonadotropin secretory dynamics during puberty in normal girls and boys. J Clin Endocrinol Metab. 1990;71(5):1251-1258

34. de Vries L, Horev G, Schwartz M, Phillip M. Ultrasonographic and clinical parameters for early differentiation between precocious puberty and premature thelarche. Eur J Endocrinol. 2006;154(6):891-898

35. Bay K, Andersson AM, Skakkebaek NE. Estradiol levels in prepubertal boys and girls: analytical challenges. Int J Androl. 2004;27(5):266-273

36. Wang C, Catlin DH, Demers LM, Starcevic B, Swerdloff RS. Measurement of total serum testosterone in adult men: comparison of current laboratory methods versus liquid chromatography-tandem mass spectrometry. J Clin Endocrinol Metab. 2004;89(2):534-543

37. Battaglia C, Mancini F, Regnani G, Persico N, Iughetti L, De Aloysio D. Pelvic ultrasound and color Doppler findings in different isosexual precocities. Ultrasound Obstet Gynecol. 2003; $22(3): 277-283$

38. Haber HP, Wollmann HA, Ranke MB. Pelvic ultrasonography: early differentiation between isolated premature thelarche 
and central precocious puberty. Eur J Pediatr. 1995;154(3): $182-186$

39. Chalumeau M, Hadjiathanasiou CG, Ng SM, et al. Selecting girls with precocious puberty for brain imaging: validation of European evidence-based diagnosis rule. J Pediatr. 2003; $143(4): 445-450$

40. Cisternino M, Arrigo T, Pasquino AM, et al. Etiology and age incidence of precocious puberty in girls: a multicentric study. $J$ Pediatr Endocrinol Metab. 2000;13(suppl 1):695-701

41. De Sanctis V, Corrias A, Rizzo V, et al. Etiology of central precocious puberty in males: the results of the Italian Study Group for Physiopathology of Puberty. J Pediatr Endocrinol Metab. 2000;13(suppl 1):687-693

42. Antoniazzi F, Zamboni G. Central precocious puberty: current treatment options. Paediatr Drugs. 2004;6(4):211-231

43. Crowley WF Jr, Comite F, Vale W, Rivier J, Loriaux DL, Cutler GB Jr. Therapeutic use of pituitary desensitization with a long-acting lhrh agonist: a potential new treatment for idiopathic precocious puberty. J Clin Endocrinol Metab. 1981; 52(2):370-372

44. Carel JC, Lahlou N, Guazzarotti L, et al. Treatment of central precocious puberty with depot leuprorelin. French Leuprorelin Trial Group. Eur J Endocrinol. 1995;132(6):699-704

45. Heinrichs C, Craen M, Vanderschueren-Lodeweyckx M, Malvaux P, Fawe L, Bourguignon JP. Variations in pituitarygonadal suppression during intranasal buserelin and intramuscular depot-triptorelin therapy for central precocious puberty. Belgian Study Group for Pediatric Endocrinology. Acta Paediatr. 1994;83(6):627-633

46. Tuvemo T, Gustafsson J, Proos LA; Swedish Growth Hormone Group. Suppression of puberty in girls with short-acting intranasal versus subcutaneous depot GnRH agonist. Horm Res. 2002;57(1-2):27-31

47. Lahlou N, Carel JC, Chaussain JL, Roger M. Pharmacokinetics and pharmacodynamics of GnRH agonists: clinical implications in pediatrics. J Pediatr Endocrinol Metab. 2000;13(suppl 1):723-737

48. Partsch CJ, Sippell WG. Treatment of central precocious puberty. Best Pract Res Clin Endocrinol Metab. 2002;16(1):165-189

49. Paterson WF, McNeill E, Young D, Donaldson MD. Auxological outcome and time to menarche following long-acting goserelin therapy in girls with central precocious or early puberty. Clin Endocrinol (Oxf). 2004;61:626-634

50. Badaru A, Wilson DM, Bachrach LK, et al. Sequential comparisons of one-month and three-month depot leuprolide regimens in central precocious puberty. J Clin Endocrinol Metab. 2006;91(5):1862-1867

51. Eugster EA, Clarke W, Kletter GB, et al. Efficacy and safety of histrelin subdermal implant in children with central precocious puberty: a multicenter trial. J Clin Endocrinol Metab. 2007;92(5):1697-1704

52. Hirsch HJ, Gillis D, Strich D, et al. The histrelin implant: a novel treatment for central precocious puberty. Pediatrics. 2005;116(6). Available at: www.pediatrics.org/cgi/content/ full/116/6/e798

53. Tanaka T, Hibi I, Kato K, et al. A dose finding study of a super long-acting luteinizing hormone-releasing hormone analog (Leuprolide acetate depot, TAP-144-SR) in the treatment of central precocious puberty [published correction appears in Endocrinol Jpn. 1992;39(3):following 329]. Endocrinol Jpn. 1991;38(4):369-376

54. Neely EK, Hintz RL, Parker B, et al. Two-year results of treatment with depot leuprolide acetate for central precocious puberty. J Pediatr. 1992;121(4):634-640

55. Carel JC, Lahlou N, Jaramillo O, et al. Treatment of central precocious puberty by subcutaneous injections of leuprorelin 3-month depot (11.25 mg). J Clin Endocrinol Metab. 2002; 87(9):4111-4116

56. Carel JC, Blumberg J, Seymour C, Adamsbaum C, Lahlou N; Triptorelin 3-Month CPP Study Group. Three-month sustained-release triptorelin (11.25 mg) in the treatment of central precocious puberty. Eur J Endocrinol. 2006;154(1): $119-124$

57. Carel JC, Lahlou N, Roger M, Chaussain JL. Precocious puberty and statural growth. Hum Reprod Update. 2004;10(2): 135-147

58. Lee PA, Page JG, Group LS. Effects of leuprolide in the treatment of central precocious puberty. J Pediatr. 1989;114(2): 321-324

59. Manasco PK, Pescovitz OH, Blizzard RM. Local reactions to depot leuprolide therapy for central precocious puberty. $J$ Pediatr. 1993;123:334-335

60. Roth C. Therapeutic potential of GnRH antagonists in the treatment of precocious puberty. Expert Opin Investig Drugs. 2002;11(9):1253-1259

61. Schultze-Mosgau A, Griesinger G, Altgassen C, von Otte S, Hornung D, Diedrich K. New developments in the use of peptide gonadotropin-releasing hormone antagonists versus agonists. Expert Opin Investig Drugs. 2005;14(9):1085-1097

62. Eugster EA. Aromatase inhibitors in precocious puberty: rationale and experience to date. Treat Endocrinol. 2004;3(3): 141-151

63. Lampit M, Golander A, Guttmann H, Hochberg Z. Estrogen mini-dose replacement during GnRH agonist therapy in central precocious puberty: a pilot study. J Clin Endocrinol Metab. 2002:87(2):687-690

64. Vottero A, Pedori S, Verna M, et al. Final height in girls with central idiopathic precocious puberty treated with gonadotropin-releasing hormone analog and oxandrolone. J Clin Endocrinol Metab. 2006;91(4):1284-1287

65. Pasquino AM, Pucarelli I, Segni M, Matrunola M, Cerroni F. Adult height in girls with central precocious puberty treated with gonadotropin-releasing hormone analogues and growth hormone [published correction appears in $J$ Clin Endocrinol Metab. 1999;84(6):1978]. J Clin Endocrinol Metab. 1999;84(2): 449-452

66. Pucarelli I, Segni M, Ortore M, Arcadi E, Pasquino AM. Effects of combined gonadotropin-releasing hormone agonist and growth hormone therapy on adult height in precocious puberty: a further contribution. J Pediatr Endocrinol Metab. 2003;16(7):1005-1010

67. Oostdijk W, Rikken B, Schreuder S, et al. Final height in central precocious puberty after long term treatment with a slow release GnRH agonist. Arch Dis Child. 1996;75(4): 292-297

68. Tanaka T, Niimi H, Matsuo N, et al. Results of long-term follow-up after treatment of central precocious puberty with leuprorelin acetate: evaluation of effectiveness of treatment and recovery of gonadal function. The TAP-144-SR Japanese Study Group on Central Precocious Puberty. J Clin Endocrinol Metab. 2005;90(3):1371-1376

69. Pasquino AM, Pucarelli I, Accardo F, Demiraj V, Segni M, Di Nardo R. Long-term observation of 87 girls with idiopathic central precocious puberty treated with gonadotropinreleasing hormone analogs: impact on adult height, body mass index, bone mineral content, and reproductive function. J Clin Endocrinol Metab. 2008;93(1):190-195

70. Antoniazzi F, Arrigo T, Cisternino $M$, et al. End results in central precocious puberty with GnRH analog treatment: the data of the Italian Study Group for Physiopathology of Puberty. J Pediatr Endocrinol Metab. 2000;13(suppl 1):773-780

71. Mul D, Oostdijk W, Otten BJ, et al. Final height after gonadotrophin releasing hormone agonist treatment for central 
precocious puberty: the Dutch experience. J Pediatr Endocrinol Metab. 2000;13(suppl 1):765-772

72. Partsch CJ, Heger S, Sippell WG. Treatment of central precocious puberty: lessons from a 15 years prospective trial. German Decapeptyl Study Group. J Pediatr Endocrinol Metab. 2000;13(suppl 1):747-758

73. Cassio A, Cacciari E, Balsamo A, Bal M, Tassinari D. Randomised trial of LHRH analogue treatment on final height in girls with onset of puberty aged 7.5-8.5 years. Arch Dis Child. 1999;81(4):329-332

74. Cassio A, Bal MO, Orsini LF, et al. Reproductive outcome in patients treated and not treated for idiopathic early puberty: long-term results of a randomized trial in adults. $J$ Pediatr. 2006; 149(4):532-536

75. Feuillan PP, Jones JV, Barnes K, Oerter-Klein K, Cutler GB Jr. Reproductive axis after discontinuation of gonadotropinreleasing hormone analog treatment of girls with precocious puberty: long term follow-up comparing girls with hypothalamic hamartoma to those with idiopathic precocious puberty. J Clin Endocrinol Metab. 1999;84(1):44-49

76. Arrigo T, De Luca F, Antoniazzi F, et al. Menstrual cycle pattern during the first gynaecological years in girls with precocious puberty following gonadotropin-releasing hormone analogue treatment. Eur J Pediatr. 2007;166(1):73-74

77. Heger S, Müller M, Ranke M, et al. Long-term GnRH agonist treatment for female central precocious puberty does not impair reproductive function. Mol Cell Endocrinol. 2006; 254-255:217-220

78. Feuillan PP, Jones JV, Barnes KM, Oerter-Klein K, Cutler GB $\mathrm{Jr}$ Boys with precocious puberty due to hypothalamic hamartoma: reproductive axis after discontinuation of gonadotropin-releasing hormone analog therapy. J Clin Endocrinol Metab. 2000;85(11):4036-4038

79. Bertelloni S, Baroncelli GI, Ferdeghini M, Menchini-Fabris F, Saggese G. Final height, gonadal function and bone mineral density of adolescent males with central precocious puberty after therapy with gonadotropin- releasing hormone analogues. Eur J Pediatr. 2000;159(5):369-374

80. Palmert MR, Mansfield MJ, Crowley WF Jr, Crigler JF Jr, Crawford JD, Boepple PA. Is obesity an outcome of gonadotropin-releasing hormone agonist administration? Analysis of growth and body composition in 110 patients with central precocious puberty. J Clin Endocrinol Metab. 1999;84(12): $4480-4488$

81. van der Sluis IM, Boot AM, Krenning EP, Drop SL, de Muinck Keizer-Schrama SM. Longitudinal follow-up of bone density and body composition in children with precocious or early puberty before, during and after cessation of GnRH agonist therapy. J Clin Endocrinol Metab. 2002;87(2):506-512

82. Antoniazzi F, Zamboni G, Bertoldo F, et al. Bone mass at final height in precocious puberty after gonadotropin-releasing hormone agonist with and without calcium supplementation. J Clin Endocrinol Metab. 2003;88(3):1096-1101

83. Arrigo T, De Luca F, Antoniazzi F, et al. Reduction of baseline body mass index under gonadotropin-suppressive therapy in girls with idiopathic precocious puberty. Eur J Endocrinol. 2004;150(4):533-537

84. Messaaoui A, Massa G, Tenoutasse S, et al. Treatment of central precocious puberty with gonadotropin-releasing hormone agonist (triptorelin) in girls: breast development, skeletal maturation, height and weight evolution during and after treatment [in French]. Rev Med Brux. 2005;26(1):27-32

85. Traggiai C, Perucchin PP, Zerbini K, Gastaldi R, De Biasio P, Lorini R. Outcome after depot gonadotrophin-releasing hormone agonist treatment for central precocious puberty: effects on body mass index and final height. Eur J Endocrinol. 2005; 153(3):463-464
86. Lazar L, Kauli R, Pertzelan A, Phillip M. Gonadotropinsuppressive therapy in girls with early and fast puberty affects the pace of puberty but not total pubertal growth or final height. J Clin Endocrinol Metab. 2002;87(5):2090-2094

87. Bertelloni S, Baroncelli GI, Sorrentino MC, Perri G, Saggese G. Effect of central precocious puberty and gonadotropinreleasing hormone analogue treatment on peak bone mass and final height in females. Eur J Pediatr. 1998;157(5): 363-367

88. Escobar ME, Ropelato MG, Ballerini MG, et al. Acceleration of luteinizing hormone pulse frequency in adolescent girls with a history of central precocious puberty with versus without hyperandrogenism. Horm Res. 2007;68(6):278-285

89. Cisternino M, Pasquino A, Bozzola $M$, et al. Final height attainment and gonadal function in girls with precocious puberty treated with cyproterone acetate. Horm Res. 1992; 37(3):86-90

90. Palmert MR, Hayden DL, Mansfield MJ, et al. The longitudinal study of adrenal maturation during gonadal suppression: evidence that adrenarche is a gradual process. J Clin Endocrinol Metab. 2001;86(9):4536-4542

91. Jensen AM, Brocks V, Holm K, Laursen EM, Müller J. Central precocious puberty in girls: internal genitalia before, during, and after treatment with long-acting gonadotropin-releasing hormone analogues. J Pediatr. 1998;132(1):105-108

92. Rosenfield RL. Identifying children at risk of polycystic ovary syndrome. J Clin Endocrinol Metab. 2007;92(3):787-796

93. Lazar L, Kauli R, Bruchis C, Nordenberg J, Galatzer A, Pertzelan A. High prevalence of abnormal adrenal response in girls with central precocious puberty at early pubertal stages. Eur J Endocrinol. 1995;133(4):407-411

94. Lazar L, Kauli R, Bruchis C, Nordenberg J, Galatzer A, Pertzelan A. Early polycystic ovary-like syndrome in girls with central precocious puberty and exaggerated adrenal response. Eur J Endocrinol. 1995;133(4):403-406

95. Steinberg L, Morris AS. Adolescent development. Annu Rev Psychol. 2001;52:83-110

96. Weichold K, Silbereisen RK, Schmitt-Rodermund E. Shortand long-term consequences of early versus late physical maturation in adolescents. In: Hayward C, ed. Puberty and Psychopathology. Cambridge, MA: Cambridge University Press; 2003:241-276

97. Susman EJ, Rogol AD. Puberty and psychological development. In: Lerner RM, Steinberg L, eds. Handbook of Adolescent Psychology. 2nd ed. Hoboken, NJ: Wiley; 2004:15-44

98. Sisk CL, Zehr JL. Pubertal hormones organize the adolescent brain and behavior. Front Neuroendocrinol. 2005;26(3-4): 163-174

99. Dorn LD. Psychological and social problems in children with premature adrenarche and precocious puberty. In: Pescovitz OH, Walvoord EC, eds. When Puberty Is Precocious: Scientific and Clinical Aspects. Totowa, NJ: Humana Press; 2007:309-327

100. Xhrouet-Heinrichs D, Lagrou K, Heinrichs C, et al. Longitudinal study of behavioral and affective patterns in girls with central precocious puberty during long-acting triptorelin therapy. Acta Paediatr. 1997;86(8):808-815

101. Grigorova M, Sherwin BB, Tulandi T. Effects of treatment with leuprolide acetate depot on working memory and executive functions in young premenopausal women. Psychoneuroendocrinology. 2006;31(8):935-947

102. Pereyra Pacheco B, Méndez Ribas JM, Milone G, et al. Use of GnRH analogs for functional protection of the ovary and preservation of fertility during cancer treatment in adolescents: a preliminary report. Gynecol Oncol. 2001;81(3): 391-397

103. Waxman JH, Ahmed R, Smith D, et al. Failure to preserve 
fertility in patients with Hodgkin's disease. Cancer Chemother Pharmacol. 1987;19(2):159-162

104. Lee SJ, Schover LR, Partridge AH, et al. American Society of Clinical Oncology recommendations on fertility preservation in cancer patients [published correction appears in $\mathrm{J}$ Clin Oncol. 2006;24(36):5790]. J Clin Oncol. 2006;24(18): 2917-2931

105. Antoniazzi F, Cisternino M, Nizzoli G, et al. Final height in girls with central precocious puberty: comparison of two different luteinizing hormone-releasing hormone agonist treatments. Acta Paediatr. 1994;83(10):1052-1056

106. Carel JC, Hay F, Coutant R, Rodrigue D, Chaussain JL. Gonadotropin releasing hormone agonist treatment of girls with constitutional short stature and normal pubertal development. J Clin Endocrinol Metab. 1996;81(9):3318-3322

107. Bouvattier C, Coste J, Rodrigue D, et al. Lack of effect of GnRH agonists on final height in girls with advanced puberty: a randomized long-term pilot study. J Clin Endocrinol Metab. 1999;84(10):3575-3578

108. Yanovski JA, Rose SR, Municchi G, et al. Treatment with a luteinizing hormone-releasing hormone agonist in adolescents with short stature. N Engl J Med. 2003;348(10):908-917

109. Lanes R, Soros A, Jakubowicz S. Accelerated versus slowly progressive forms of puberty in girls with precocious and early puberty: gonadotropin suppressive effect and final height obtained with two different analogs. J Pediatr Endocrinol Metab. 2004; 17(5):759-766

110. Tuvemo T. Treatment of central precocious puberty. Expert Opin Investig Drugs. 2006;15(5):495-505

111. Carel JC. Management of short stature with GnRH agonist and co-treatment with growth hormone: a controversial issue. Mol Cell Endocrinol. 2006;254-255:226-233

112. Pasquino AM, Pucarelli I, Roggini M, Segni M. Adult height in short normal girls treated with gonadotropin-releasing hormone analogs and growth hormone. J Clin Endocrinol Metab. 2000;85(2):619-622

113. van Gool SA, Kamp GA, Visser-van Balen H, et al. Final height outcome after three years of growth hormone and gonadotropin-releasing hormone agonist treatment in short adolescents with relatively early puberty. $J$ Clin Endocrinol Metab. 2007;92(4):1402-1408

114. Mul D, Oostdijk W, Waelkens JJ, Drop SL. Final height after treatment of early puberty in short adopted girls with gonadotrophin releasing hormone agonist with or without growth hormone. Clin Endocrinol (Oxf). 2005;63(2):185-190

115. Clayton PE, Cianfarani S, Czernichow P, Johannsson G, Rapaport R, Rogol A. Management of the child born small for gestational age through to adulthood: a consensus statement of the International Societies of Pediatric Endocrinology and the Growth Hormone Research Society. J Clin Endocrinol Metab. 2007;92(3):804-810

116. Teng L, Bui H, Bachrach L, et al. Catch-up growth in severe juvenile hypothyroidism: treatment with a $\mathrm{GnRH}$ analog. J Pediatr Endocrinol Metab. 2004;17(3):345-354

117. Carel JC, Ecosse E, Nicolino M, et al. Adult height after long-term recombinant growth hormone treatment for idiopathic isolated growth hormone deficiency: observational follow-up study of the French population-based registry. BMJ. 2002;325(7355):70-73

118. Reiter EO, Lindberg A, Ranke MB, et al. The KIGS experience with the addition of gonadotropin-releasing hormone agonists to growth hormone $(\mathrm{GH})$ treatment of children with idiopathic GH deficiency. Horm Res. 2003;60(suppl 1):68-73

119. Mul D, Wit JM, Oostdijk W, Van den Broeck J; Dutch Advisory Group on Growth Hormone. The effect of pubertal delay by GnRH agonist in GH-deficient children on final height. J Clin Endocrinol Metab. 2001;86(10):4655-4656

120. Mericq MV, Eggers M, Avila A, Cutler GB Jr, Cassorla F. Near final height in pubertal growth hormone (GH)-deficient patients treated with GH alone or in combination with luteinizing hormone-releasing hormone analog: results of a prospective, randomized trial. J Clin Endocrinol Metab. 2000;85(2): 569-573

121. Saggese G, Federico G, Barsanti S, Fiore L. The effect of administering gonadotropin-releasing hormone agonist with recombinant-human growth hormone $(\mathrm{GH})$ on the final height of girls with isolated GH deficiency: results from a controlled study. J Clin Endocrinol Metab. 2001;86(5): 1900-1904

122. Tanaka T, Satoh M, Yasunaga T, et al. When and how to combine growth hormone with a luteinizing hormonereleasing hormone analogue. Acta Paediatr Suppl. 1999; 88(428):85-88

123. Mericq V, Gajardo H, Eggers M, Avila A, Cassorla F. Effects of treatment with GH alone or in combination with LHRH analog on bone mineral density in pubertal GH-deficient patients. J Clin Endocrinol Metab. 2002;87(1):84-89

124. Lin-Su K, Vogiatzi MG, Marshall I, et al. Treatment with growth hormone and luteinizing hormone releasing hormone analog improves final adult height in children with congenital adrenal hyperplasia. J Clin Endocrinol Metab. 2005; 90(6):3318-3325

125. Geier DA, Geier MR. A clinical trial of combined antiandrogen and anti-heavy metal therapy in autistic disorders. Neuro Endocrinol Lett. 2006;27(6):833-838 


\section{Consensus Statement on the Use of Gonadotropin-Releasing Hormone Analogs in Children}

Jean-Claude Carel, Erica A. Eugster, Alan Rogol, Lucia Ghizzoni and Mark R. Palmert

Pediatrics 2009;123;e752; originally published online March 30, 2009; DOI: $10.1542 /$ peds. $2008-1783$

\section{Updated Information \& Services}

References

Citations

Subspecialty Collections

Permissions \& Licensing

Reprints including high resolution figures, can be found at: http://pediatrics.aappublications.org/content/123/4/e752.full.h tml

This article cites 118 articles, 60 of which can be accessed free at:

http://pediatrics.aappublications.org/content/123/4/e752.full.h tml\#ref-list-1

This article has been cited by 11 HighWire-hosted articles: http://pediatrics.aappublications.org/content/123/4/e752.full.h tml\#related-urls

This article, along with others on similar topics, appears in the following collection(s):

\section{Office Practice}

http://pediatrics.aappublications.org/cgi/collection/office_pra ctice

Information about reproducing this article in parts (figures, tables) or in its entirety can be found online at:

http://pediatrics.aappublications.org/site/misc/Permissions.xht $\mathrm{ml}$

Information about ordering reprints can be found online: http://pediatrics.aappublications.org/site/misc/reprints.xhtml

PEDIATRICS is the official journal of the American Academy of Pediatrics. A monthly publication, it has been published continuously since 1948. PEDIATRICS is owned, published, and trademarked by the American Academy of Pediatrics, 141 Northwest Point Boulevard, Elk Grove Village, Illinois, 60007. Copyright @ 2009 by the American Academy of Pediatrics. All rights reserved. Print ISSN: 0031-4005. Online ISSN: 1098-4275.

\section{American Academy of Pediatrics}

DEDICATED TO THE HEALTH OF ALL CHILDREN ${ }^{m}$ 